\title{
Effects add kefir grains to whey cheese on chemical and microbiological qualities
}

\author{
Mustofa Hilmi *, Anis Usfah Prastujati, Asmaul Khusna, Muhammad Habbib Khirzin, Deni \\ Yannuarista
}

\author{
Study Program of Livestock Product Processing Technology \\ State Polytechnic of Banyuwangi, Jalan Raya Jember - Banyuwangi Km. 13, Labanasem, \\ Kabat, Banyuwangi, Jawa Timur, Indonesia
}

\section{Submitted: 13 Nopember 2018, Accepted: 8 Maret 2019}

\begin{abstract}
Whey is liquid cheese waste produced from the cheese making process after being separated from the curd. Cheese production waste contains a carbon source, one of which is lactose as an energy source in the development of fermented biotechnology, especially the manufacture of probiotics for livestock. Lactose (4-7\%) and protein (0.6-1\%) in whey cheese can be used as a medium for the growth of lactic acid bacteria and yeast in producing secondary metabolites which could be applied as nutraceutical feed additives that were useful for medical or health, including prevention and treatment of diseases and improve livestock performance.The research purpose was to determine the effect of adding kefir grain 1-5\% into whey cheese based on chemical quality and microbiological. Whey Cheese is mixed with $10 \%$ molasses and then heated at $80^{\circ} \mathrm{C}$ for 10 minutes later the temperature is lowered between $35-40{ }^{\circ} \mathrm{C}$ and added starter according to treatment. The next step is incubating anaerobic kefir fermentation for 24 hours with temperatures between $35-40^{\circ} \mathrm{C}$. The experimental method was designed with a completely randomized design with 6 starter level treatments and 3 replications, namely $0 \%, 1 \%, 2 \%, 3 \%, 4 \%, 5 \%$. The results showed that the addition of $1-5 \%$ kefir grain was very significant $(\mathrm{P}<0.01)$ increasing protein, lactic acid bacteria, yeast and reducing water, fat, Total Plate Count (TPC). It can be concluded study concludes that the addition of 5\% kefir grain into whey cheese added with $10 \%$ molasses affects the increase in lactic and yeast acid bacteria, protein and decreases fat, water, Total Plate Count (TPC).
\end{abstract}

Keywords: cheese; fermentation; kefir grain; whey. 


\section{INTRODUCTION}

Whey is liquid cheese waste produced from the cheese making process after being separated from the curd. Whey liquid which is not used in the community can cause environmental pollution if it is directly disposed of without being processed (Prasetyo and Kustiawan, 2012; Prastujati, Hilmi, and Khirzin, 2018). According to Nursiwi, Utami, Andriani, and Sari (2015) that cheese waste liquid contains a carbon source, one of which is lactose as an energy source in the development of fermented biotechnology, especially the manufacture of probiotics for livestock.

Lactose (4-7\%) and protein (0.6-1\%) contained in whey can be used as a medium for bacterial growth in the process of fermentation biotechnology is very beneficial for animal health and increases the productivity of organic livestock(Prasetyo and Kustiawan, 2012). The content of lactose and protein can be utilized in the development of lactic and yeast acid bacteria (yeast) as a medium for increasing biomass and producing several bioactive components through fermentation (Ariyanti and Hadiyanto, 2013; Nursiwi et al., 2015; Watson and Preedy, 2015).

Fermentation is the process of decomposing chemicals by lactic acid bacteria, yeast, or other microorganisms to produce several bioactive components such as organic acids (lactic acid), active peptides and proteins that act as antibacterial, antioxidant, and immunity. According to Watson and Preedy (2015), fermentation products have a role in helping the process of absorption of vitamins D and $\mathrm{K}$, stimulating the growth of beneficial bacteria in the small intestine and helping the process of absorption of various micro-substances such as minerals such as calcium ions and iron. The fermented nutrient content can be applied as a nutraceutical feed additive for livestock (Charalampopoulos and Rastall, 2009; Kabir, 2009; Mellor, 2000;
Sugiharto, 2016; Watson and Preedy, 2015). Nutraceutical feed additives are feed additives that provide medical or health benefits, including the prevention and treatment of diseases and increasing performance and livestock production (Bhattacharya, 2015; M Hilmi and Astuti, 2015).

The use of lactic acid bacteria and yeast for fermentation one of them uses kefir grain. Kefir grains are exopolysaccharides consisting of microorganisms immobilized in the polysaccharide matrix and protein, where several species of lactic acid bacteria and yeast coexist in symbiotic associations (Farnworth and Mainville, 2008; Garrote, Abraham, and De Antoni, 2010). In microbial ecosystems, there is a relatively stable population of microorganisms, which interact and influence other members of the microbial community (Leite et al., 2013). This population provides a synthesis of bioactive metabolites, which are essential for increasing the growth of kefir grains and inhibition of pathogen microorganisms and contamination (Garrote et al., 2010).

\section{MATERIAL AND METHODS}

Whey cheese was obtained by $\mathrm{CV}$. Margo Utomo around July-June 2018 mixed $10 \%$ molasses and then proximate analysis (Table 1.). The stages of cheese waste fermentation include taking whey and then heating it at $80^{\circ} \mathrm{C}$ for 10 minutes then adding $10 \%$ molasses. The temperature drop was quickly carried out to temperatures of $35-40^{\circ} \mathrm{C}$ with soaking beaker glass containing a mixture of whey cheese and molasses into the cold water. The next step was adding the injection to the starter of kefir grain according to the treatment. After the inoculation process was completed, it was followed by incubation of anaerobic kefir fermentation for 24 hours with temperatures between $35-40^{\circ} \mathrm{C}$ (Kesenkaş, Gürsoy, and Özbaş, 2017; 
Türkmen, Akal, and Koçak, 2014; White,

Kilara, and Hui, 2008).

Table 1 . The chemical composition of whey

\begin{tabular}{cc}
\hline Item & $(\%)$ \\
\hline Moisture & 76.96 \\
Ash & 4.65 \\
Protein & 0.20 \\
Carbohydrate & 17.95 \\
Sucrose & 8.38 \\
Acetic acid & 0.26 \\
Lactose & 7.85 \\
pH & 4.70 \\
\hline
\end{tabular}

Sumber : Mustofa Hilmi, Prastujati, Khusna, and Khirzin (2018)

\section{Research Methods}

The experimental design used in this study was a completely randomized design with six treatments and three replications. The data obtained were subjected to oneway ANOVA analysis and if the treatment had a significant effect $(\mathrm{P}<0.05)$ and $(\mathrm{P}<0.01)$ followed by the Duncan test. The treatments tested include $0 \%$ Grain Kefir (control), 1\% Grain Kefir, 2\% Grain Kefir, $3 \%$ Grain Kefir, 4\% Grain Kefir, 5\% Grain Kefir.

\section{Chemical Quality Measurement of Whey Fermentation \\ Moisture Test}

Analysis of water content using an oven. Water content was calculated as weight percent, meaning how many grams of weight of the sample with the weight difference of the sample that has not been evaporated with the sample that has been (dried). The water content can be obtained by calculating the weight loss of the heated sample. The working sequence is as follows: - Porcelain cup with lid was cleaned and dried in an oven at a temperature of $105-110^{\circ} \mathrm{C}$ for 1 hour. Then it was cooled in a desiccator for 30 minutes and weighed (A gram) - The sample was considered as much as 2 grams and placed in a porcelain dish whose weight was known (B gram). The porcelain sample was then dried in an oven at a temperature of the $105-110^{\circ} \mathrm{C}$ constant sample for 24 hours, then cooled in a desiccator for 30 minutes and weighed (C gram) - This weighing was repeated until a constant weight was obtained (Nielsen, 2017).

\section{Protein Levels}

Determination of protein content testing using the Kjeldahl method. This method was used to analyze crude protein levels in food ingredients indirectly because what was investigatedwas nitrogen levels. By multiplying the results of the analysis with conversion rates, protein values will be obtained in the material (Nielsen, 2017).

\section{Fat Content Analysis}

Determination of fat content according to the Soxhlet method in principle was that food ingredients were dried until they are free of water and then dissolved in ether or benzene. The results obtained were not pure fat, but a mixture of various substances, namely: chlorophyll, xanthophyll, carotene, and others, so it was more accurately called crude fat (Nielsen, 2017).

\section{Microbiological Measurement of Whey Fermentation \\ Analysis of the Amount of Lactic Acid Bacteria}

Determination of the number of lactic acid bacteria in the liquid fermented cheese was diluted into $0.1 \% 9 \mathrm{ml}$ peptone solu- 
tion (this solution is $10^{-1}$ dilution), then continued dilution to $10^{-8}$. In the last three series of dilutions, the sample was taken 1 $\mathrm{ml}$ each and poured into a petri dish which was filled with MRSA media. MRSA media which contained the sample was incubated with temperature and incubation time according to the treatment. Colony growth in each cup was calculated according to the time of incubation. Calculated the number of TPC in $1 \mathrm{~g}$ by multiplying the average number of colonies with dilution factors used with units of colony forming units /g or colonies/g (Cappuccino and Sherman, 2013).

\section{Analysis of Yeast Amount}

Determination of the number of lactic acid bacteria in fermented cheese liquid sample diluted into $0.1 \% 9 \mathrm{ml}$ peptone solution (this solution is 10-1 dilution), then continued dilution to $10-8$. In the last three series of dilutions, the sample was taken 1 $\mathrm{ml}$ each and poured into a petri dish which was filled with MRSA media. MRSA media which contained the sample was incubated with temperature and incubation time according to the treatment. Colony growth in each cup was calculatedaccording to the time of incubation. Calculated the number of TPC in $1 \mathrm{~g}$ by multiplying the average number of colonies with dilution factors used with units of colony forming units / $\mathrm{g}$ or colonies / $\mathrm{g}$ (Cappuccino and Sherman, 2013).

\section{Testing of Total Plate Count (TPC)}

TPC testing was carried out by diluting $1 \mathrm{ml}$ of whey $+9 \mathrm{ml}$ of distilled water to the fourth dilution (104). $1 \mathrm{ml}$ of whey that hadbeen adulteratedwas then dropped into petrifilm (3M TM Petrifilm TM Anaerobic Bactery). Petrifilm was then incubated in an incubator at $37^{\circ} \mathrm{C}$ for 48 hours. The total calculation of microorganisms carried out after the incubation period ends by calculating red-colored spots on petrifilm (Cappuccino and Sherman, 2013).

\section{RESULTS AND DISCUSSION Effect of adding kefir grain to chemical quality \\ Fat}

The effect of adding kefir grains to cheese whey had a very significant impact ( $p<0.01)$ on fat content in fermented whey. The control treatment without the addition of kefir grain was very significant ( $p$ $<0.01$ ) higher than other treatments (Table $2)$. The decrease in fat levels in the treatment was caused by the overhaul of the lipase enzyme produced by enzymeproducing bacteria, namely lactic acid bacteria in the kefir grain. Dinçer and Kıvanç (2018)decreasing the fat content of the substrate was caused by a fat revision by the lipase enzyme produced by lactic acid bacteria used as energy. Lipase enzyme was an enzyme that can hydrolyze ester bonds, especially neutral fats such as triglycerides (Konwar and Sagar, 2018).

\section{Protein}

The effect of increasing the concentration of kefir grain on protein content was very significant $(\mathrm{p}<0.01)$ increasing compared to the control (Figure 1). The average increase in protein was $8.7 \%-27.6 \%$ compared to Control (Table 2). The increase in the average protein was $8.7 \%$ $27.6 \%$ compared to the Control (Table 2). This increase in protein was caused by the addition of a starter number of $1-5 \%$ which results in an increase in the number of bacteria in the kefir granules using sucrose derived from molasses in carrying out metabolic activities (Zakaria, 2008). Increased sugar levels (sucrose and lactose) will occur microbial activity in synthesizing proteins. Rumeen, Yelnetty, Tamasoleng, and Lontaan (2017) the increasing energy contained in an average increase in metabolic activity or enzymatic and chemical reactions produced. Furthermore, Sawitri (2012) increased the concentration of kefir grains which increased high protein levels ranging from $40-60 \%$, the presence of lac- 
tose will increase the proliferation of microorganisms in the kefir grains, during the fermentation process there will be the multiplication of cells in large quantities.

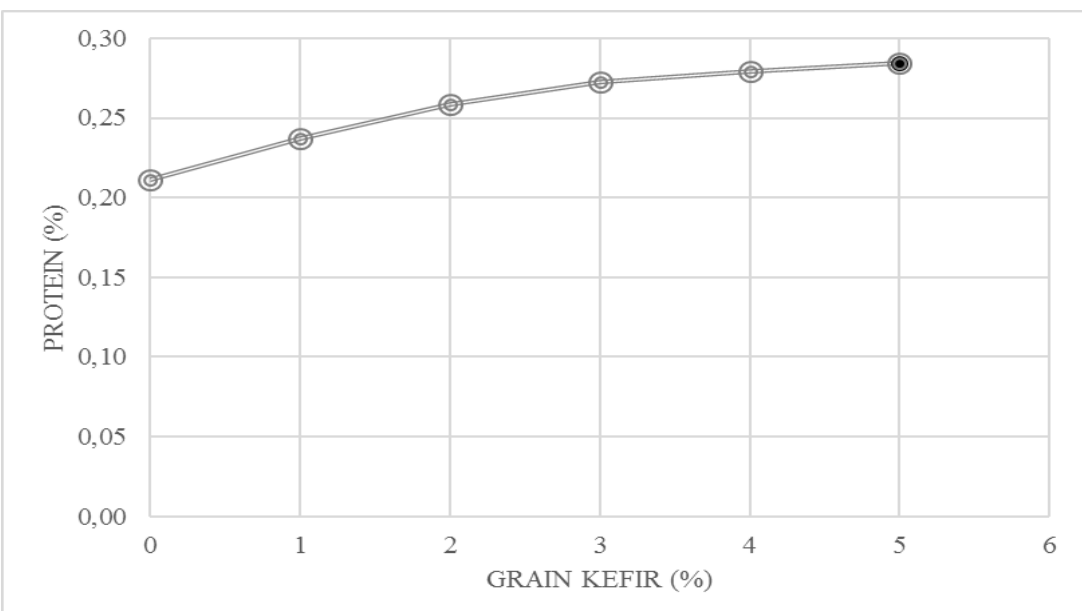

Figure1. Effect of Adding Kefir Grain in Whey Cheese to Increased Protein Levels

\section{Ash content}

The effect of adding kefir grains to cheese whey had a very significant impact $(\mathrm{p}<0.01)$ on decreasing ash content. The increase of $0-1 \%$ of kefir grain was very significant $(\mathrm{p}<0.01)$ higher compared to other treatments (Table 2). The treatment of 3-4\% of kefir grain was significantly higher than the $5 \%$ treatment. The addition of the concentration of kefir grain was added, it will decrease the ash content in each solution compared to the treatment without giving kefir grain. The average ash content of fermentation in this study canbe seen in Table 2. This decrease in ash con- tent could occur because in the fermentation process there will be an increase in organic matter, due to the process of degradation of material (substrate) by microbes. increasing the amount of kefir grain concentration between 1-5\% will increase the degradation of organic materials such as sucrose, lactose, protein, and fat. The less organic matter was degraded, the less proportion of relative ash decreases proportionally, on the contrary, the more organic material is degraded, the more proportional increase in ash content will be (Styawati, 2014).

Table 2. Effect of adding kefir grain to chemical quality

\begin{tabular}{llllllll}
\hline \multirow{2}{*}{ Items $(\%)$} & \multicolumn{2}{l}{ Kefir Grain Levels (\%) } & \multicolumn{2}{l}{ SEM } \\
& 0 (Kontrol) & 1 & 2 & 3 & 4 & 5 & \\
\hline Fat & $0.23^{\mathrm{A}}$ & $0.21^{\mathrm{B}}$ & $0.18^{\mathrm{C}}$ & $0.20^{\mathrm{B}}$ & $0.12^{\mathrm{B}}$ & $0.18^{\mathrm{C}}$ & 0.01 \\
Protein & $0.21^{\mathrm{E}}$ & $0.23^{\mathrm{D}}$ & $0.26^{\mathrm{C}}$ & $0.27^{\mathrm{B}}$ & $0.28^{\mathrm{AB}}$ & $0.29^{\mathrm{A}}$ & 0.01 \\
Ash & $2.71^{\mathrm{A}}$ & $2.56^{\mathrm{A}}$ & $2.51^{\mathrm{C}}$ & $2.59^{\mathrm{B}}$ & $2.58^{\mathrm{B}}$ & $2.42^{\mathrm{C}}$ & 0.03 \\
\hline
\end{tabular}

${ }^{\mathrm{A}-\mathrm{D}}$ Different letter in the same row indicatessignificantly different (Duncan test, $\mathrm{P}<0.01$ ).

SEM: standard error means

The effect of adding grain kefir to microbiology

\section{Lactic acid bacteria (LAB)}

The addition of kefir grain into whey has a very significant effect $(\mathrm{P}<0.01)$ increasing lactic acid bacteria (LAB) (Table $3)$.The treatment of adding $1-5 \%$ of kefir grain was authentic $(\mathrm{P}<0.01)$ increasing the 
number of lactic acid bacteria compared to controls (without kefir grain) (Graph 2).The increasing number of lactic acid bacteria was caused by increasing levels of kefir grain concentration and the presence of sucrose contained in the treatment. According Prastiwi, Bintoro, and Rizqiati (2018) that lactic acid bacteria in kefir grains will hydrolyze sucrose from molasses which will undergo the process of glycolysis to pyruvate and reduced by lactic acid bacteria to lactic acid and energy used for cell proliferation and growth of lactic acid bacteria. Based on this, it could be said that whey and molasses had sugar content such as lactose and sucrose which can be used as a good source of nutrition for lactic acid bacteria to grow and develop(Nursiwi et al., 2015; Rosiana, 2013; Rumeen et al., 2017)

\section{Yeast (Saccharomyces cerevisiae)}

The addition of grain kefir had a very significant effect $(\mathrm{p}<0.01)$ on the increase in yeast (Table 3 ). The treatment of adding $1-5 \%$ of kefir grain was very significant $(p$ $<0.01$ ) increasing the amount of yeast compared to the control (without kefir grain). The average number of yeasts in the treatment ranged from 6.13-8.72 log $\mathrm{CFU} / \mathrm{ml}$ (Figure 2). The increase in the amount of yeast was due to increasing levels of kefir grain concentration and the presence of sucrose contained in the treatment added with molasses. Yeast in the kefir grain will hydrolyze sucrose from molasses which will undergo the process of glycolysis to pyruvate and be reduced by the yeast to alcohol and energy used for breeding and cell growth.(Ariyanti and Hadiyanto, 2013; Kim et al., 2015). Furthermore, Aristya, Legowo, and AlBaarri (2013)Saccharomyces cerevisiae had a characteristic that is easier to digest sucrose causing the faster growth of Saccharomyces cerevisiae compared to DPsicose sugar. Saccharomyces cerevisiae is also a simple sugar user and not a lactose user so that Saccharomyces cerevisiae will use glucose from the breakdown of lactose by L. acidophilus. Ide (2013) that the example of yeast instead of lactose fermentation is Saccharomyces cerevisiae.

Table 3. The Effect of kefir grain addition on the characteristics of microbiology

\begin{tabular}{|c|c|c|c|c|c|c|c|}
\hline \multirow{2}{*}{ Items } & \multicolumn{6}{|c|}{ Kefir Grain Levels (\%) } & \multirow[t]{2}{*}{ SEM } \\
\hline & 0 (Kontrol) & 1 & 2 & 3 & 4 & 5 & \\
\hline LAB ( $\log$ & & & & & & & \\
\hline $\mathrm{CFU} / \mathrm{ml})$ & $2.62^{\mathrm{D}}$ & $9.91^{\mathrm{C}}$ & $10.14^{\mathrm{B}}$ & $10.27^{\mathrm{AB}}$ & $10.37^{\mathrm{A}}$ & $10.44^{\mathrm{A}}$ & 0.69 \\
\hline TPC (Log & & & & & & & \\
\hline $\mathrm{CFU} / \mathrm{ml})$ & $2.93^{\mathrm{b}}$ & $2.56^{\mathrm{a}}$ & $2.78^{\mathrm{a}}$ & $2.60^{\mathrm{a}}$ & $2.47^{\mathrm{a}}$ & $2.56^{\mathrm{a}}$ & 0.15 \\
\hline Yeast (Log & & & & & & & \\
\hline $\mathrm{CFU} / \mathrm{ml})$ & $6.13^{\mathrm{B}}$ & $8.30^{\mathrm{A}}$ & $8.72^{\mathrm{A}}$ & $8.11^{\mathrm{A}}$ & $8.46^{\mathrm{A}}$ & $8.20^{\mathrm{A}}$ & 0.01 \\
\hline
\end{tabular}

LAB:lactic acid bacteria. TPC: Total Plate Count. ${ }^{\text {a-c. }}$ A-C Means followed by a different lowercase letter in the same row were significantly different at $\mathrm{P}<0.005$; Means followed by a different capital letter in the same row were significantly different at $(\mathrm{P}<0.01)$. SEM:standard error means

\section{Total Plate Count (TPC)}

Addition of kefir grain into whey cheese had a significant effect $(\mathrm{P}<0.05)$ increasing lactic acid bacteria (LAB) (Table $3)$.The treatment of adding $1-5 \%$ of the real grain kefir $(\mathrm{P}<0.05)$ decreased TPC along with the high percentage of kefir grain (Graph 2) causes some pathogenic bacteria in the treatment to die due to the increased antibacterial lactic and acetic acid content in some pathogenic bacteria.This was known based on the results of total lactic acid bacteria testing which increases with increasing percentage of kefir grain (Wulandari, Purwadi, and Jaya, 2017). Kesenkaş et al. (2017) explained that the 
addition of kefir grain also causes the kefir $\mathrm{pH}$ to decrease which causes pathogenic bacteria that cannot stand with a low $\mathrm{pH}$ will be blocked or die. Furthermore (Londero et al., 2011; Wulandari et al., 2017) explained that there are four factors that influence the antibacterial activity of honey. namely high sugar levels that will inhibit bacteria so that the bacteria cannot live and develop. the high acidity of honey will reduce growth and bacterial survival. so the bacteria will die. the hydrogen peroxide radical $\left(\mathrm{H}_{2} \mathrm{O}_{2}\right)$ which can kill pathogenic microorganisms and the presence of organic compounds. Organic compounds that had identified as having antibacterial activity are "inhibited."

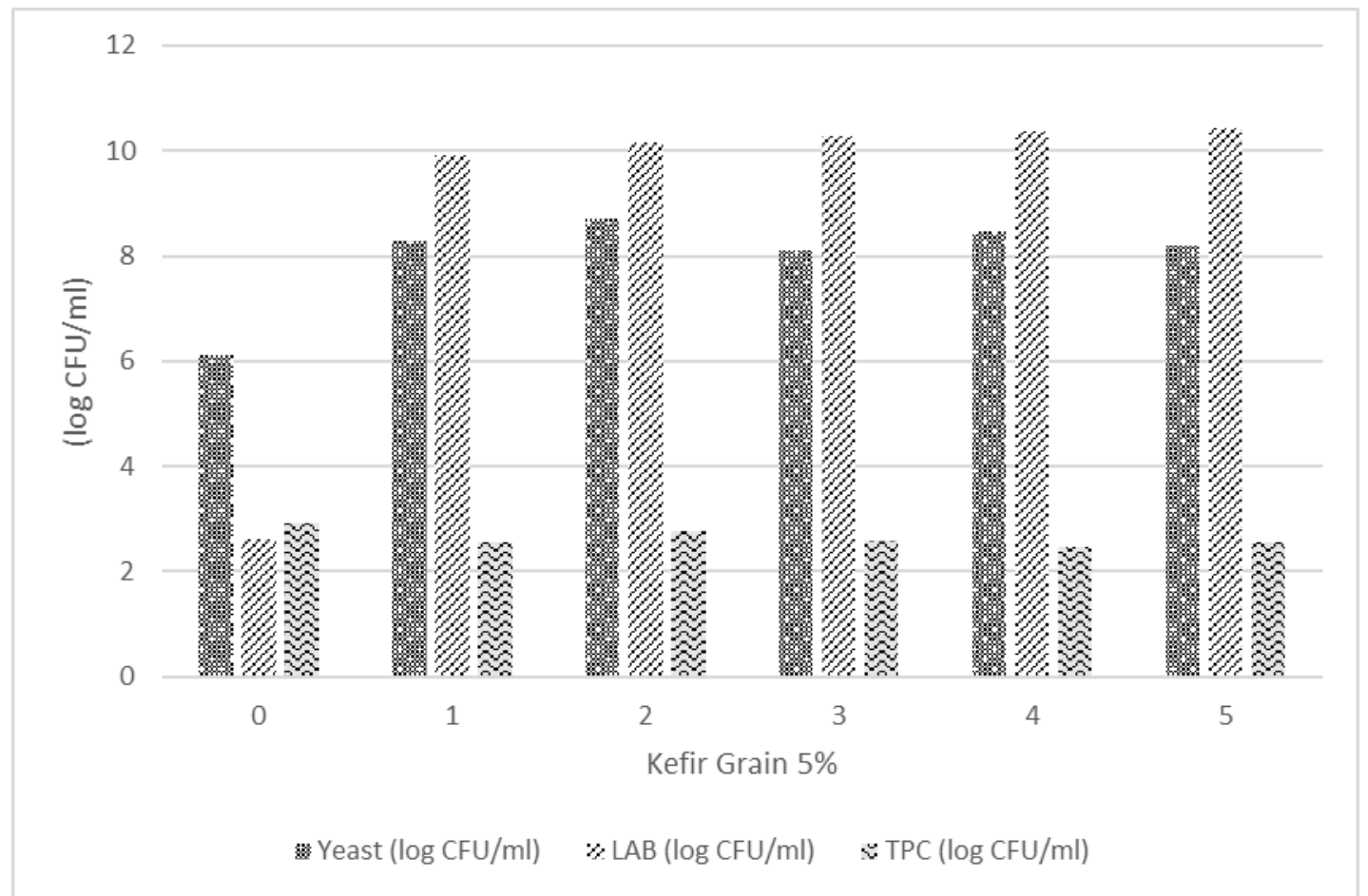

Figure 2. Effect of addition of kefir grain in whey cheese on characteristics of microbiology

\section{CONCLUSION}

The addition of $5 \%$ kefir grains to whey cheese added with $10 \%$ molasses affects the increase in lactic and yeast acid bacteria, protein and decreases fat, water, TPC (Total Plate Count).

\section{ACKNOWLEDGMENT}

Thanks to Politeknik Negeri Banyuwangi for the funding that has been given in the scheme Research of PNBP funding sources in 2018. Second time to the research team for their cooperation so that we can complete our research activity.

\section{REFERENCES}

Aristya, A. L., Legowo, A. M., and AlBaarri, A. N. 2013. Total asam, total yeast, dan profil protein kefir susu kambing dengan penambahan jenis dan konsentrasi gula yang berbeda. Jurnal Pangan dan Gizi, 4(1), 39-48.

Ariyanti, D., and Hadiyanto, H. 2013. Pembuatan Bioetanol Dari Limbah Keju (Whey) Melalui Proses Fermentasi Fed-batch Dengan Kluyveromyces Marxianus. Jurnal Teknologi Kimia dan Industri, 2(2), 155-162. 
Bhattacharya, A. 2015. Nutraceuticals in Livestock and Poultry: New India Publishing Agency.

Cappuccino, J., and Sherman, N. 2013. Microbiology: a laboratory manual, books a la Carte Edition: Benjamin-Cummings Publishing Company.

Charalampopoulos, D., and Rastall, R. A. 2009. Prebiotics and probiotics science and technology (Vol. 1): Springer.

Dinçer, E., and Kıvanç, M. 2018. Lipolytic Activity of Lactic Acid Bacteria Isolated from Turkish Pastırma. Anadolu Üniversitesi Bilim ve Teknoloji Dergisi-C Yaşam Bilimleri Ve Biyoteknoloji, 7(1), 1219.

Farnworth, E. R., and Mainville, I. 2008. Kefir-A fermented milk product Handbook of Fermented Functional Foods, Second Edition (pp. 89127): CRC Press.

Garrote, G. L., Abraham, A. G., and De Antoni, G. L. 2010. Microbial Interactions in Kefir: A natural probiotic drink. Biotechnology of Lactic Acid Bacteria: Novel Applications, 327.

Hilmi, M., and Astuti, D. 2015. Egg production and physical quality in cortunix cortunix japonica fed diet containing piperine as phytogenic feed additive. Media peternakan, $38(3), 150-155$.

Hilmi, M., Prastujati, A. U., Khusna, A., and Khirzin, M. H. 2018. Effect of adding kefir grains to the chemical quality and antioxidants of whey. Scholars Journal of Agriculture and Veterinary Sciences, 5(10), 557-562.

Ide, P. 2013. Health Secret Of Kefir: Elex Media Komputindo.

Kabir, S. M. L. 2009. The Role of Probiotics in the Poultry Industry. International Journal of Molecular Sciences, 10(8), 3531-3546.

Kesenkaş, H., Gürsoy, O., and Özbaş, H. 2017. Chapter 14 - Kefir. In J. Frias, C. Martinez-Villaluenga, \& E. Peñas (Eds.), Fermented Foods in Health and Disease Prevention (pp. 339-361). Boston: Academic Press.

Kim, D. H., Chon, J. W., Kim, H., Kim, H. S., Choi, D., Hwang, D. G., and Seo, K. H. 2015. Detection and enumeration of lactic acid bacteria, acetic acid bacteria and yeast in kefir grain and milk using quantitative real-time PCR. Journal of Food Safety, 35(1), 102-107.

Konwar, B. K., and Sagar, K. 2018. Lipase: an industrial enzyme through metagenomics: Apple Academic Press.

Leite, A. M. d. O., Miguel, M. A. L., Peixoto, R. S., Rosado, A. S., Silva, J. T., and Paschoalin, V. M. F. 2013. Microbiological, technological and therapeutic properties of kefir: a natural probiotic beverage. Brazilian Journal of Microbiology, 44(2), 341-349.

Londero, A., Quinta, R., Abraham, A. G., Sereno, R., Antoni, G. D., and Garrote, G. L. 2011. Inhibitory activity of cheese whey fermented with kefir grains. Journal of Food Protection, 74(1), 94-100. 
Mellor, S. 2000. Nutraceuticals alternatives to antibiotics. World Poultry, 16(2), 30-31,33.

Nielsen, S. S. 2017. Food Analysis Laboratory Manual: Springer International Publishing.

Nursiwi, A., Utami, R., Andriani, M., and Sari, A. P. 2015. Fermentasi whey limbah keju untuk produksi kefiran oleh kefir grains. Jurnal Teknologi Hasil Pertanian, 8(1), 37-45.

Prasetyo, B., and Kustiawan, E. 2012. Pemanfaatan whey fermentasi sebagai "funtional feed" dalam meningkatkan performans ayam broiler. Jurnal Ilmiah Inovasi, 12(1), 84-88.

Prastiwi, V. F., Bintoro, V. P., and Rizqiati, H. 2018. Sifat mikrobiologi, nilai viskositas dan organoleptik kefir optima dengan penambahan High Fructose Syrup (HFS). Jurnal Teknologi Pangan, 2(1), 27-32.

Prastujati, A. U., Hilmi, M., and Khirzin, M. H. 2018. Pengaruh konsentrasi starter terhadap kadar alkohol, $\mathrm{pH}$, dan total asam tertitrasi (TAT) whey kefir (the effect of starter concentration on alcohol, $\mathrm{pH}$, and total titrated acids (TTA) in whey kefir). Jurnal Ilmu Peternakan Terapan, 2(1), 18-24.

Rosiana, E. 2013. Kadar asam laktat dan derajat asam kefir susu kambing yang difermentasi dengan penambahan gula dan lama inkubasi yang berbeda. Jurnal Medika Veterinaria, 7(2), 87-90.

Rumeen, S. F., Yelnetty, A., Tamasoleng, M., and Lontaan, N. 2017. Penggunaan level sukrosa terhadap sifat sensoris kefir susu sapi. ZOOTEC, 38(1), 123-130.

Sawitri, M. E. 2012. Kajian konsentrasi kefir grain dan lama simpan dalam refrigerator terhadap kualitas kimiawi kefir rendah lemak. Jurnal Ilmu-ilmu Peternakan, 21(1), 2328.

Styawati, N. E. 2014. Pengaruh lama fermentasi Trametes sp. terhadap kadar bahan kering, kadar abu, dan kadar serat kasar daun nenas varietas Smooth cayene. Jurnal Ilmiah Peternakan Terpadu, 2(1), 19-24.

Sugiharto, S. 2016. Role of nutraceuticals in gut health and growth performance of poultry. Journal of the Saudi Society of Agricultural Sciences, 15(2), 99-111.

Türkmen, N., Akal, C., and Koçak, C. 2014. Use of whey in Kefir production. Journal of Biotechnology, 185, S84-S85.

Watson, R. R., and Preedy, V. R. 2015. Probiotics, Prebiotics, and Synbiotics: Bioactive Foods in Health Promotion: Academic Press.

White, C. H., Kilara, A., and Hui, Y. 2008. Manufacturing yogurt and fermented milks: John Wiley \& Sons.

Wulandari, A., Purwadi, P., and Jaya, F. 2017. Penambahan madu bunga kopi (Coffea sp.) terhadap kualitas kefir ditinjau dari karakteristik mikrobiologi. Jurnal Ilmu dan Teknologi Hasil Ternak (JITEK), 12(2), 83-88.

Zakaria, Y. 2008. Sifat kimia, mikrobiologi dan organoleptik yogurt yang 
menggunakan persentase

Lactobacillus casei dan kadar gula

yang berbeda. Jurnal Agripet, 8(1),

21-24. 